\title{
CYTOGENETICS OF THE BRAZILIAN WHIPTAIL LIZARD Cnemidophorus littoralis (TEIIDAE) FROM A RESTINGA AREA (BARRA DE MARICÁ) IN SOUTHEASTERN BRAZIL
}

\author{
PECCININI-SEALE, D., ${ }^{1}$ ROCHA, C. F. D., ${ }^{2}$ ALMEIDA, T. M. B., ${ }^{3}$ \\ ARAÚJO, A. F. B. ${ }^{4}$ and DE SENA, M. A. ${ }^{1}$ \\ ${ }^{1}$ Instituto de Biociências, Universidade de São Paulo, C.P. 11461, CEP 05422-970, São Paulo, SP, Brazil \\ ${ }^{2}$ Departamento de Ecologia, Instituto de Biologia Roberto Alcantara Gomes, Universidade do Rio de Janeiro, \\ Rua Francisco Xavier, 524, Maracanã, CEP 20550-011, Rio de Janeiro, RJ, Brazil \\ ${ }^{3}$ Instituto Butantã, São Paulo, SP, Brazil \\ ${ }^{4}$ Universidade Federal Rural do Rio de Janeiro, RJ, Brazil \\ Correspondence to: Carlos Frederico D. Rocha, Departamento de Ecologia, Instituto de Biologia Roberto \\ Alcantara Gomes, Universidade do Rio de Janeiro, Rua Francisco Xavier, 524, Maracanã, \\ CEP 20550-011, Rio de Janeiro, RJ, Brazil, e-mail: cfdrocha@uerj.br \\ Received November 13, 2002 - Accepted September 23, 2003 - Distributed August 31, 2004
}

(With 4 figures)

\begin{abstract}
Chromosomes of Cnemidophorus littoralis, a new species of teiid lizard recently described, were studied. The animals are from a restinga area in Barra de Maricá, RJ. The karyotype presents a diploid number of $2 n=46$ chromosomes and a chromosomal sex determination mechanism of the type XX:XY. Nucleolar organizer regions, Ag-NORs, are at the sixth pair of chromosomes; there is variability of size and number of the Ag-stained nucleoli on the 50 interphase nuclei for each specimen analyzed. These nucleoli are related to NOR patterns that also demonstrated variability in size and number. This paper presents the first description of the karyotype of Cnemidophorus littoralis and of a chromosomal sex determination mechanism of the XX:XY type in the genus Cnemidophorus from Southeastern Brazil.
\end{abstract}

Key words: restinga, lizards, karyotype, sex chromosomes.

\section{RESUMO}

\section{Citogenética de Cnemidophorus littoralis (Teiidae) da restinga da Barra de Maricá no Sudeste do Brasil}

Estudamos os cromossomos de Cnemidophorus littoralis, uma nova espécie de lagarto recentemente descrita, pertencente à família Teiidae. Os animais são oriundos de uma população de restinga na Barra de Maricá, RJ. O cariótipo apresenta número diplóide $2 \mathrm{n}=46$ cromossomos, com mecanismo cromossômico de determinação do sexo do tipo XX:XY. As regiões organizadoras do nucléolo, Ag-RONs, estão no sexto par de cromossomos. Analisamos 50 núcleos interfásicos corados pela prata para cada exemplar e observamos variação quanto ao número e ao tamanho de nucléolos; estes estão relacionados aos padrões RONs, que também apresentaram variação quanto ao tamanho e ao número. Este trabalho também descreve pela primeira vez a presença de um mecanismo de determinação cromossômica do sexo para o gênero Cnemidophorus do Sudeste do Brasil.

Palavras-chave: restinga, lagartos, cariótipo, cromossomos sexuais, espécie endêmica. 


\section{INTRODUCTION}

Within the family Teiidae, chromosomes of Cnemidophorus and Ameiva genera have been intensively studied. Cnemidophorus contains 32 species with numerical and structural variability in the karyotypes, chromosomal numbers ranging from 46 to 52 in diploid species, 69 to 71 in triploids, and 92 in tetraploids (Peccinini-Seale, 1969; Gorman, 1970; Peccinini-Seale, 1981, 1989). The karyotype variation observed in this genus indicates that centric fusions and/or fissions and pericentric inversions have occurred.

The sex determination mechanisms in Sauria are not yet completely understood. Sex chromosome evolution in lizards is considered to be relatively recent and data from some families suggest that they have multiple origins (Beçak, 1983). There are species with chromosomal sex determination mechanisms ascribed to male heterogamety in the families Iguanidae (see Frost \& Etheridge, 1989), Lacertidae, Teiidae, Scincidae, and Pygopodidae; female heterogamety is known in the families Gekkonidae, Varanidae, and Lacertidae (for a review, see Peccinini-Seale, 1981 and references therein). In the genus Cnemidophorus, Cole et al. (1969) and Bull (1978) reported a chromosomal sex determination mechanism of the type $\mathrm{XX}$ :XY for Cnemidophorus tigris.

The genus Cnemidophorus Wagler 1830 has about forty-seven species described according to Maslin \& Secoy (1986) and forty-five species, according to Wright (1993). These species are found over a wide range of open habitats in North, Central, and South America (Peters \& Donoso-Barros, 1986) with higher species diversity in North America. The teiid Cnemidophorus of South America is distributed over three main species groups: lemniscatus, ocellifer, and lacertoides. There are five species from the lemniscatus complex in Brazilian Amazonia alone, C. lemniscatus (karyotype D), C. cryptus (karyotypes A, B, C), C. gramivagus (karyotype E); one in Guiana, C. pseudolemniscatus (karyotype F) (Peccinini-Seale \& Frota-Pessoa, 1974; Ávila-Pires, 1995; Cole \& Dessauer, 1993); and one in Venezuela, C. arenivagus (Markezich et al., 1997). From the ocellifer species group, besides C. ocellifer (which is found over a wide range of open area habitats from northeastern and central Brazil southward to northern Argentina), five other species have recently been described: $C$. nativo (Rocha et al., 1997), C. littoralis (Rocha et al., 2000), C. abaetensis (Dias et al., 2002), C. parecis (Colli et al., 2003), and C. mumbuca (Colli et al., 2003); Cei (1993) recognized three species in the lacertoides group: C. lacertoides, C. leachei, and $C$. serranus; Feltrim \& Lema (2000) recently described C. vacariensis.

The cogeneric Cnemidophorus lemniscatus from Brazilian Amazonia is apparently related to $C$. ocellifer, but they have never been seen in simpatry (Peccinini-Seale, pers. obs.). Several populations of C. lemniscatus have been intensively studied so as to clarify the nature and origins of parthenogenesis within the group (Peccinini-Seale, 1989; Sites et al., 1990, and references therein). Geographic variation exists in the karyotype; while no chromosomal sex determination mechanism has been found. Within South American lizards, only two other species of Cnemidophorus, besides those of the lemniscatus group, have been karyotyped: the bisexual species C. lacertoides (Cole et al., 1979) and the unisexual species C. nativo (Rocha et al., 1997).

Cnemidophorus nativo, previously considered as $C$. ocellifer, was recently described as a new species by Rocha et al. (1997). This was also the first description, within the ocellifer group, of a new unisexual population of lizards with diploid thelytok parthenogenesis and chromosomal structural heterozygosity. Recently, a new species called $C$. vacariensis of the lacertoides group has been described by Feltrim \& Lema (2000). In addition, four new species from the ocellifer group have recently been described: $C$. littoralis, an endemic species from the coastal areas of Rio de Janeiro State in Southeastern Brazil (Rocha et al., 2000); C. abaetensis, which is endemic in the sand dune habitats of Salvador (Dunas de Abaeté) and the northern coast of Bahia State (Dias et al., 2002); C. parecis (Colli et al., 2003), and C. mumbuca (Colli et al., 2003). This study describes the karyotype and the meiosis of a population of the endemic $C$. littoralis from the locality type for the species (Restinga da Barra de Maricá in Rio de Janeiro State, Southeastern Brazil), which presents a chromosomal sex determination mechanism of the type XX:XY.

\section{MATERIAL AND METHODS}

The karyotype of a population of $C$. littoralis from a restinga area of Barra de Maricá (22 $57^{\prime} 50^{\prime \prime} \mathrm{S}$ and $43^{\circ} 50^{\prime} 40^{\prime \prime} \mathrm{W}$ ), in Maricá County, Rio de Janeiro State, Southeastern Brazil is described. Restingas 
are coastal salt-sand dune habitats covered with sparse herbaceous and shrubby vegetation common to the Brazilian coast (Suguio \& Tessler, 1984). This species is endemic to Rio de Janeiro State, with a northern limit of distribution at Grussaí. The geographically nearest species of the genus is $C$. nativo whose distribution is restricted to Espírito Santo State, north of the Doce River, and Southern Bahia State (Rocha et al., 1997).

Cytogenetic analyses were conducted via techniques adapted for lizards by Peccinini-Seale \& Almeida (1986). Chromosome preparations were obtained from suspensions of bone marrow cells from the femur and vertebral column and of intestinal epithelial cells. Meiotic chromosomal spreads were prepared from testis cell suspension adapted for lizards by Peccinini et al. (1971). We used conventional Giemsa staining to analyze mitotic and meiotic chromosomes. For each of the six male individuals from Barra de Maricá we analyzed at least 11-21 complete metaphases. Nucleolar organizer regions, Ag-NORs, were stained according to Peccinini-Seale \& Almeida (1986), modified for lizards by Bloom
\& Goodpasture (1976) and Howell \& Black (1980). The chromosome nomenclature follows Levan et al. (1964) and the karyotype description, Peccinini-Seale (1981). We made the photographs on a Zeiss microscope with $1250 \mathrm{X}$ magnification.

\section{RESULTS AND DISCUSSION}

The male karyotype of $C$. littoralis from Barra de Maricá is shown in Fig. 1. Metaphase analyses showed a diploid number of 46 chromosomes $(2 n=$ 46), with 24 macrochromosomes, of which 5 were submetacentric and 19 were telocentric and subtelocentric; there were 22 microchromosomes, the majority of which were telocentric and subtelocentric. The karyotype of this population may be represented as $2 n=46(5 ; 19 ; 22)$. The sixth pair is heteromorphic, suggesting the occurrence of sex chromosomes of $\mathrm{XY}$ type, in which $\mathrm{X}$ is a large submetacentric and $\mathrm{Y}$ is a medium-sized telocentric. This corresponds to the first description of a XX: $\mathrm{XY}$ sex determination mechanism in the genus Cnemidophorus in Southeastern Brazil.

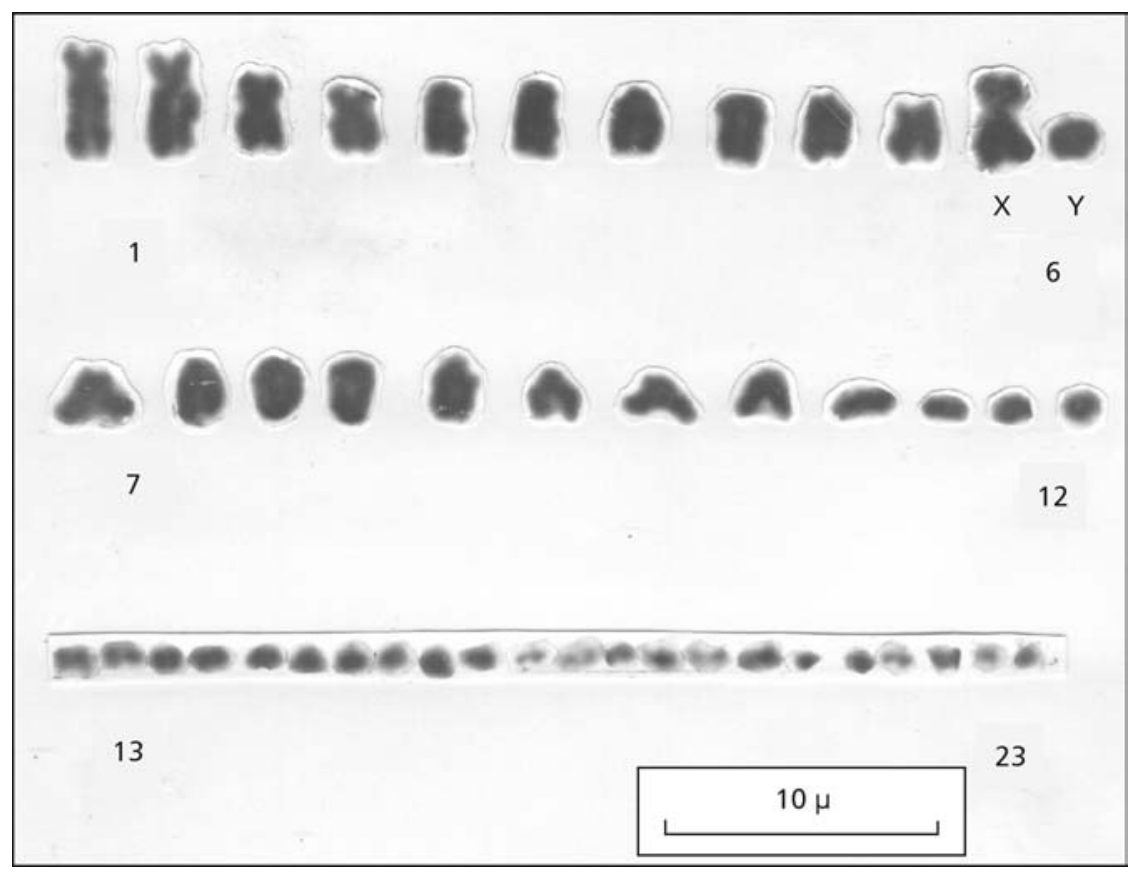

Fig. 1 - Karyotype of Cnemidophorus littoralis; male, mitotic intestine epithelial cells; $2 \mathrm{n}=46$ chromosomes; $46(5,19,22)$ $\mathrm{XX}, \mathrm{XY}$; heteromorphic sex chromosomes in the sixth pair; conventional staining. 
Silver staining showed Ag-NORs in the eighth pair of chromosomes in the telomeric region (Fig. $2)$. There was variability in number (2-3 nucleoli) and size (small, medium, and large) of nucleoli in the 50 interphase cells analyzed (Fig. 3). This could indicate variability in ribosomal DNA transcription by the nucleoli organizers (Ruiz et al., 1984). The study of male meiosis showed 23 bivalents in the diakinesis-metaphase I cells; 12 bivalents are macrochromosomes and 11 bivalents, microchromosomes (Fig. 4). The bivalent 12, however, is unpaired, suggesting the presence of a heteromorphic pair (arrow, Fig. 4). This unpaired bivalent may also indicate the presence of a chromosomal difference related to a XX:XY sexual pair, which may be considered additional evidence of the occurrence of an XX:XY chromosomal sex determination mechanism in this species.

A higher number of cells in diakinesis-metaphase I should be analyzed. However, the seven meiotic cells in diakinesis-metaphase I showed a partially paired bivalent between two chromosomes of different sizes. This bivalent may be related to chromosomes which differ in morphology and in the size of the sixth pair, which has one large submetacentric and one small telocentric, observed in metaphase cells from mitotic preparations. Earlier stages of meiosis, preleptotene, leptotene, zygotenepachytene, and also metaphase II were observed.

The karyotype described for $C$. littoralis in this study is different in number and morphology of chromosomes from all the studied karyotypes of Cnemidophorus. Within South American lizards, the other species of the genus Cnemidophorus with this karyotype description are: several populations of three species of the Brazilian C. lemniscatus group; a few populations of one species of the $C$. lemniscatus group from Guyana with cytotype F; that of $C$. lacertoides; and that of the unisexual $C$. nativo. The bisexual and parthenogenetic populations of the Brazilian C. lemniscatus group have diploid numbers of 48 and 50 chromosomes and five different cytotypes: A, B, C, unisexual; D, E, bisexual. The first pair of chromosomes is homozygote or heterozygote for a pericentric inversion (PeccininiSeale, 1989). Cnemidophorus lacertoides has 50 chromosomes and the third pair of chromosomes is homozygote for a pericentric inversion (Cole et al., 1979). Cnemidophorus nativo has 48 chromosomes and the second, seventh, and thirteenth pairs of chromosomes are heterozygote for pericentric inversions; the homologues are heteromorphic, differing in total relative length and centromere position (Rocha et al., 1997).

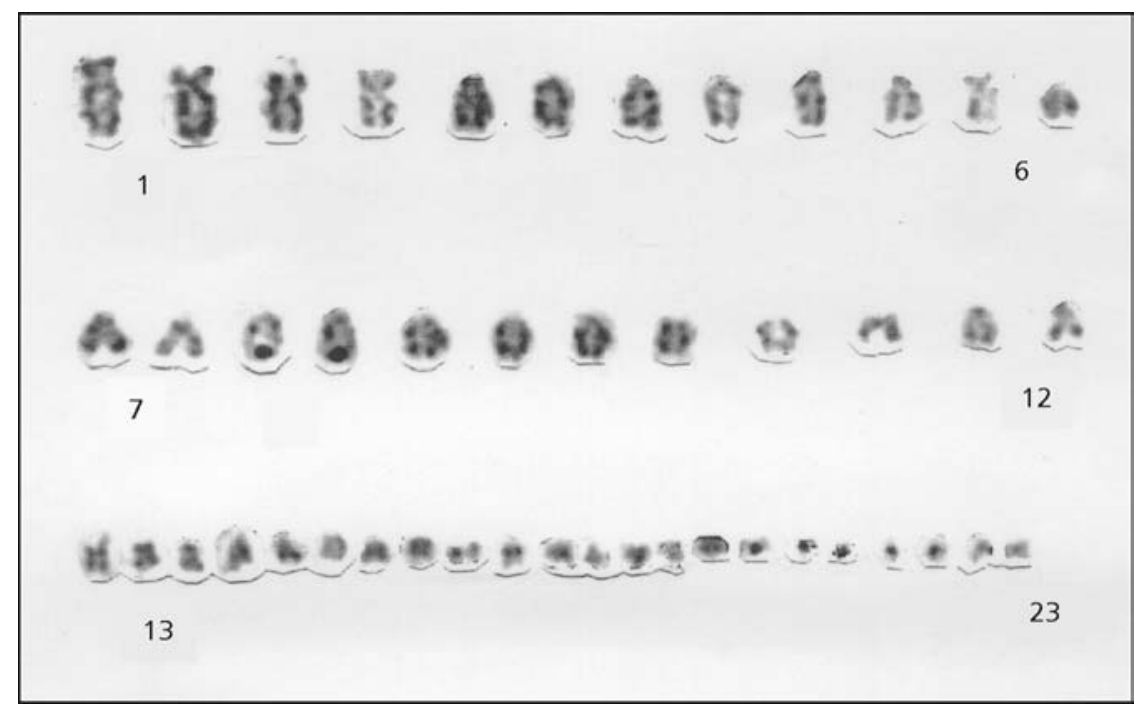

Fig. 2 - Karyotype of Cnemidophorus littoralis; male; mitotic metaphase; intestine epithelial cells; $2 \mathrm{n}=46$ chromosomes; 46 $(5,19,22) \mathrm{XX}, \mathrm{XY}$; heteromorphic sex chromosomes in the sixth pair; Ag-NORs in the eighth pair of chromosomes. 

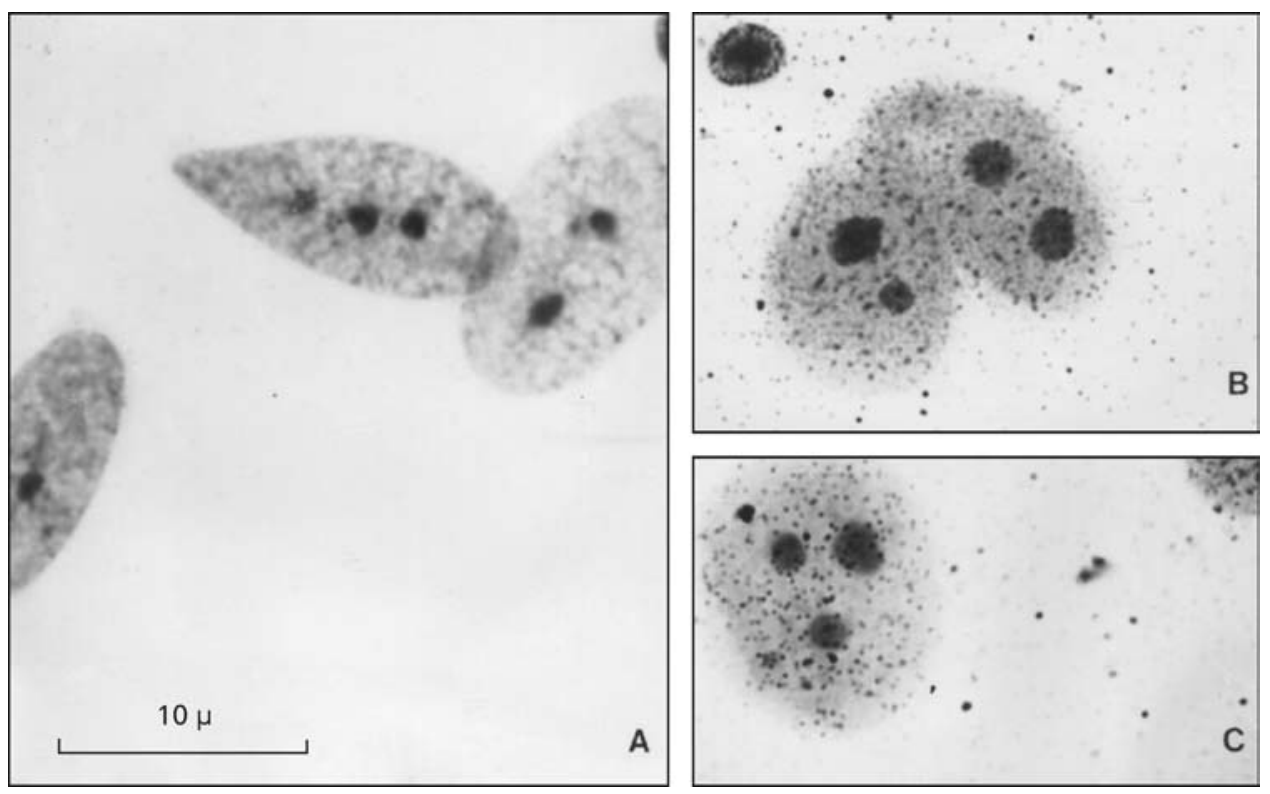

Fig. 3 - Interphase nuclei of intestine epithelial cells with variability in the number (1 to 3 ) and size of nucleoli. (A) Conventional staining; (B, C) silver nitrate precipitate staining.
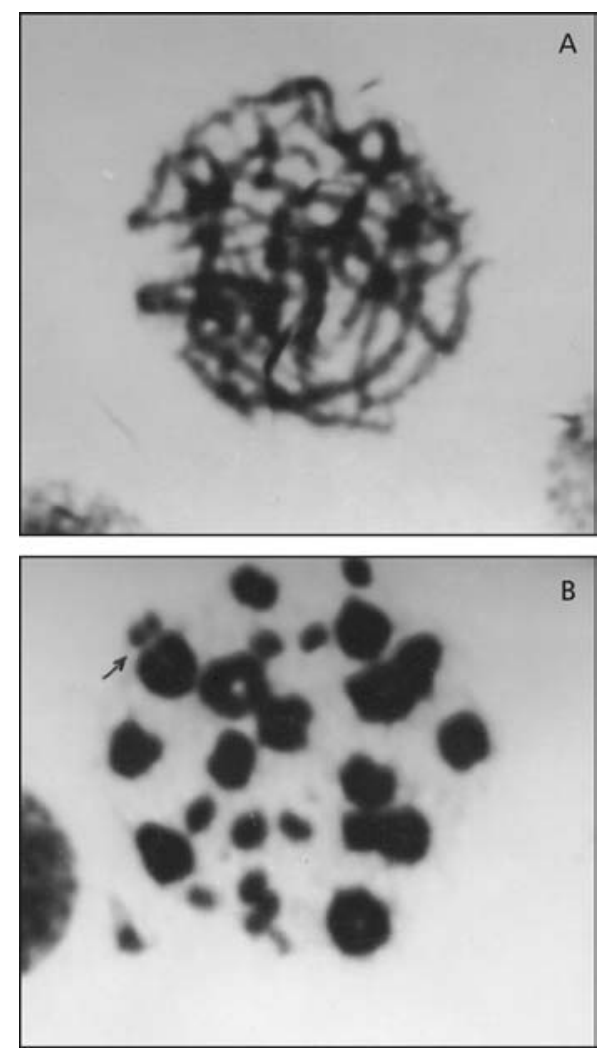

Fig. 4 - Meiosis in Cnemidophorus littoralis; male; testis; (A) zygotene-pachytene; (B) diakinesis-metaphase I with 23 bivalents; conventional staining. Arrow indicates the heteromorphic bivalent. 
In comparing the karyotype of $C$. littoralis from Maricá with those of other species of Cnemidophorus from South America, an interspecific variation in the karyotypes is observed. There is a reduction in the diploid number in $C$. littoralis due to centric fusions of microchromosomes. In this species, pericentric inversions occurred in the first and second pairs of chromosomes, which are of the submetacentric type. The XX:XY sex chromosomes are the most striking difference in the $C$. littoralis karyotype; these are not found in any other Cnemidophorus species.

Silver staining technique showed different patterns of ribosomal gene activity in $C$. littoralis in accordance with differences found in the size of Ag-NORs. In five karyotypes of the C. lemniscatus group and in the $C$. nativo karyotype, the Ag-NORs are also found in the eighth pair of chromosomes along with variability in the size of Ag-NORs.

Cnemidophorus lizards may constitute a group of different species or disjunct populations of one species undergoing rapid speciation, as in the case of unisexual and bisexual populations of the Cnemidophorus lemniscatus group from Brazilian Amazonia (Peccinini-Seale, 1989). We may assume this, based on the cascading chromosomal speciation model proposed by Hall (1973), which is similar to the stasipatric model of White (1968). The overall situation here examined generally resembles one proposed by Bickham \& Baker (1979), whereby chromosomal rearrangements may become fixed by genetic drift in small, inbred demes, which subsequently undergo range expansion which is assumed to result in a competitive advantage.

Acknowledgements - We thank the BIOTA Program, financed by Fundação de Amparo à Pesquisa do Estado de Estado de São Paulo, BIOTA/FAPESP, for a research grant awarded to DPS (Process No. 99/ 08291-5). We also thank the Conselho Nacional do Desenvolvimento Científico e Tecnológico (CNPq) for research grants made available to DPS (Process N. 407394/ 87-7) and CFDR (Processes N. 300 819/94-3 and 477981/20038 ), and a grant for undergraduate scientific studies (PIBIC-CNPQ) to MAS.

\section{REFERENCES}

ÁVILA-PIRES, T. C. S., 1995, Lizards of Brazilian Amazonia. Zoologische Verhandeligen, 299: 1-706.

BEÇAK, W., 1983, Evolution and differentiation of sex chromosome in lower vertebrates. Differentiation, 23(supl.): 3-12.

BICKHAM, J. W. \& BAKER, R. J., 1979, Canalization model of chromosomal evolution. Bulletin of Carnegie Museum of Natural History, 13: 70-84.
BLOOM, S. E. \& GOODPASTURE, C., 1976, An improved technique for selective staining of nucleolar organizer regions in human chromosomes. Hum. Genet., 34: 199-206.

BULL, J. J., 1978, Sex chromosome differentiation: an intermediate stage in a lizard. Canadian Journal of Genetics and Cytology, 20: 205-209.

CEI, J. M., 1993, Reptiles del Noroeste. Nordeste y Este de la Argentina. Museo Regionale di Scienze Naturali, Torino.

COLE, C. J. \& DESSAUER, H. C., 1993, Unisexual and bisexual whiptail lizards of the Cnemidophorus lemniscatus complex (Squamata: Teiidae) of the Guiana region, South America, with description of new species. American Museum Novitates, 3081: 1-30.

COLE, C. J., LOWE, C. H. \& WRIGHT, J. W., 1969, Sex chromosomes in teiid whiptail lizards genus Cnemidophorus. American Museum Novitates, 2395: 1-14.

COLE, C. J., McCOY, C. J. \& ACHAVAL, F., 1979, Karyotype of a South American teiid lizard Cnemidophorus lacertoides. American Museum Novitates, 2671: 1-5.

COLLI, G., CALDWELL, J. P., COSTA, G. C., GAINSBURY, A. L., GARDA, A. A., MESQUITA, D. O., FILHO, C. M. M. R., SOARES, A. H. B., SILVA, V. N., VALDUJO, P. H., VIEIRA, G. H. C., VITT, L. J., WERNECK, F. P., WIEDERIIECKER, H. C. \& GATZ, M. G., 2003, A new species of Cnemidophorus (Squamata, Teiidae) from the Cerrado Biome in Central Brazil. Occ. Pap. San Noble Mus. Nat Hist., 14: 1-14.

COLLI, G., COSTA, G. C., GARDA, A. A., KOPP, K. A., MESQUITA, D. O., PÉRES, A. K. Jr., VALDUJO, P. H., VIEIRA, G. H. C. \& WIEDERHECKER, H., 2003, A critically endangered new species of Cnemidophorus (Squamata, Teiidae) from a Cerrado enclave in Southwestern Amazonia, Brazil. Herpetologica, 59(1): 76-88.

DIAS, E. J. R., ROCHA, C. F. D. \& VRCIBRADIC, D., 2002, New Cnemidophorus (Squamata: Teiidae) from Bahia State, Northern Brazil. Copeia, 2002(4): 928-937.

FELTRIM, A. C. \& LEMA, T., 2000, Uma nova espécie de Cnemidophorus Wagler, 1830 do Estado do Rio Grande do Sul, Brasil (SAURIA, TEIIDAE). Biociencias, Porto Alegre, 8(1): 103-114.

FROST, D. R. \& ETHERIDGE, R., 1989, A phylogenetic analysis and taxonomy of iguanian lizards (Reptilia: Squamata). Misc. Publ. Mus. Nat. Hist. Univ. Kansas, 81: 1-65.

GORMAN, G. C., 1970, Chromosomes and the systematics of the family Teiidae (Sauria: Reptilia). Copeia, 2: 230-245.

GORMAN, G. C., ATKINS, L. \& HOLZINGER, T., 1967, New karyotypic data on 15 genera of lizards in the Family Iguanidae, with a discussion of taxonomic and cytological implications. Cytogenetics, 6: 286-299.

HALL, W. P., 1973, Comparative population cytogenetics, speciation and evolution of the iguanid lizard genus Sceloporus. Unpublished Ph.D. Diss., Harvard University, Cambridge.

HOWELL, W. M. \& BLACK, D. A., 1980, Controlled silver staining of nucleolar organizer regions with a protective colloidal developer. A one-step method. Experientia, 36: 10141015 . 
LEVAN, A., FREDGA, K. \& SANDBERG, A. A., 1964 Nomenclature for centromeric position on chromosomes. Hereditas, 52(2): 201-220.

MASLIN, T. P. \& SECOY, D. M., 1986, A checklist of the lizard genus Cnemidophorus (Teiidae). Contrib. Zool. Colorado Mus., 1: 1-60.

MARKEZICH, A. L., COLE, J. C. \& DESSAUER, H. C., 1997, The blue and green whiptail lizards (Squamata: Teiid Cnemidophorus) of the Peninsula de Paraguana, Venezuela: Systematics, Ecology, Descriptions of two new taxa and relationships to whiptails of the Guianas. American Museum Novitates, 3207: 1-60.

PECCININI-SEALE, D., 1969, Cariótipo e mecanismo de determinação do sexo em algumas espécies de lacertílios brasileiros (Iguanidae e Teiidae). Est. Acad. Fac. Fil. Ciênc., Letr, Univ. São Paulo, 95: 1-46.

PECCININI-SEALE, D., 1981, New developments in vertebrate cytotaxonomy. IV. Cytogenetic studies in reptiles. Genetica, 56: $123-148$.

PECCININI-SEALE, D., 1989, Genetic studies on bisexual and unisexual populations of amazonian Cnemidophorus, pp. 241-251, In: R. M. Dawley \& J. P. Bogart (eds.), Evolution and ecology of unisexual vertebrates. New York State University Press, Albany, New York.

PECCININI, D., FROTA-PESSOA, O. \& FERRARI, I., 1971, Sex determination of the pseudoXO/XX type in the Brazilian lizard Polychrus sp. (Sauria, Iguanidae). Caryologia, 24: 129-139.

PECCININI-SEALE, D. \& FROTA-PESSOA, O., 1974, Structural heterozygozyty in parthenogenetic populations of Cnemidophorus lemniscatus (Sauria: Teiidae) from the Amazonas Valley. Chromosoma, 47: 439-451.

PECCININI-SEALE, D. \& ALMEIDA, T. M. B., 1986 , Chromosomal variation, nucleolar organizers and constitutive heterochromatin in the genus Ameiva and Cnemidophorus (Sauria, Teiidae). Caryologia, 39: 227-237.
PETERS, J. A. \& DONOSO-BARROS, R., 1986, Catalogue of the Neotropical Squamata. Part II. Lizards and Amphisbaenians. Smithsonian Institution Press, Washington, DC.

ROCHA, C. F. D., BERGALLO, H. G. \& PECCININI-SEALE, D., 1997, Evidence of a unisexual population of the Brazilian whiptail lizard genus Cnemidophorus (Sauria, Teiidae) with description of a new species. Herpetologica, 53(3): 374 382.

ROCHA, C. F. D., ARAÚJO, A. F. B., VRCIBRADIC, D. \& COSTA, E. M. M., 2000, New Cnemidophorus (Squamata, Teiidae) from coastal Rio de Janeiro State, Southeastern Brazil. Copeia, 2000(2): 501-509.

RUIZ, I. R. G., ALMEIDA, T. M. B. \& BECAK, W., 1984, Active nucleolar organizer regions in polyploid populations of Odontophrynus americanus (Amphibia, Anura) from South Brazil. Genetica, 1-37.

SITES, J. W., Jr., PECCININI-SEALE, D. M., MORITZ, C., WRIGHT, J. W. \& BROWN, W. M., 1990, The evolutionary history of parthenogenetic Cnemidophorus lemniscatus (Sauria: Teiidae). I. Evidence for a hybrid origin. Evolution, 44: 906-921.

SUGUIO, K. \& TESSLER, M. G., 1984, Planícies de cordões litorâneos Quaternários do Brasil: origem e nomenclatura, pp. 15-25. In: L. D. Lacerda, D. S. D. Araújo, R. Cerqueira \& B. Tucq (eds.), Restingas: origem, estrutura, processos. Centro Editorial da Universidade Federal Fluminense.

WHITE, M. J. D., 1968, Models of speciation. Science, 159: 1065-1070.

WRIGHT, J. W., 1993, Evolution of the lizards of the genus Cnemidophorus, pp. 27-81. In: J. W. Wright \& L. J. Vitt (eds.), Biology of the whiptail lizards (genus Cnemidophorus). Norman, Oklahoma Mus. Nat. Hist. 